\title{
Implementation of PAI Learning Outcomes in Student Discipline in State Elementary School 15 Sungai Geringging Padang Pariaman Regency
}

\author{
Nurtib J. \\ Guru Pendidikan Agama Islam di SD Negeri 15 Sungai Geringging Kabupten Padang Pariaman \\ nurtibj@gmail.com
}

\section{ARTICLE INFO}

\section{Article History:}

Received: June 3, 2021

Revised: June 23, 2021

Accepted: August 30,

2021

Published: October 31, 2021

*Corresponding

Author:

Name:Nurtib J.

Email:nurtibj@gmail.co $\mathrm{m}$

Phone/WA:

081363228664

Keyword

\section{ABSTRACT}

PAI learning is expected to produce changes in the behavior, attitudes and morals of learners, because actually the main orientation of PAI learning is the realization of learners who are able to practice Islamic teachings in accordance with the material that has been studied. Based on the above thoughts, this study aims to reveal how PAI learning outcomes are implemented for the discipline of learners in the school environment. This research uses qualitative methods, namely revealing data and facts in the form of sentences that can be understood by readers. The result of this study is that PAI learning results have not been implemented in the discipline of learners, the conclusion is based on research data that shows there are still learners who have not instilled discipline in the school environment.

\section{Abstrak}

Pembelajaran PAI diharapkan dapat menghasilkan perubahan tingkah laku, sikap dan akhlak peserta didik, karena sesungguhnya orientasi utama dari pembelajaran PAI ialah terwujudnya peserta didik yang mampu mengamalkan ajaran Islam sesuai dengan materi yang telah dipelajari. Berdasarkan pemikiran di atas, penelitian ini bertujuan untuk mengungkapkan bagaimana hasil pembelajaran PAI diimplementasikan untuk kedisiplinan peserta didik di lingkungan sekolah. Penelitian ini menggunakan metode kualitatif, yakni mengungkapkan data dan fakta dalam bentuk kalimat yang dapat dipahami oleh para pembaca. Hasil penelitian ini ialah bahwa hasil pembelajaran PAI belum terimplementasikan dalam kedisiplinan peserta didik, kesimpulan didasarkan pada data penelitian yang menunjukkan masih terdapatnya peserta didik yang belum menanamkan sikap kedisiplinan di lingkungan sekolah. Temuan ini berbeda dengan kesimpulan dan teori yang telah ada yang menyatakan bahwa hasil pembelajaran PAI membentuk peserta didik menjadi pribadi yang disiplin. Perbedaan ini disebabkan beberapa factor, seperti perbedaan pola pikir peserta didik yang belum memiliki kematangan berpikir. 


\section{INTRODUCTION}

Pendidikan merupakan hal yang penting dalam membentuk karakter peserta didik, salah satu karakter yang semestinya lahir dan terbentuk melalui proses pendidikan adalah penanaman nilai kedisiplinan dan tanggung jawab (A. Nugroho, 2020). Peran guru dibutuhkan dalam menanamkan dan menumbuhkan kedisiplinan pada peserta didik (Dzivhani, 2000; Gui et al., 2020). Disiplin sebagai bagian dari karakter yang akan dibina melalui pembelajaran akan menjadikan peserta didik menjadi manusia yang mampu menjalani kehidupan dengan mematuhi aturan yang ada.

Pembelajaran sebagai suatu kegiatan kombinasi yang tersusun meliputi unsurunsur manusia, fasilitas, perlengkapan dan prosedur yang saling mempengaruhi untuk mencapai tujuan pembelajaran (Schunk, 2012; Barrett et al., 2015). Pendidikan Agama Islam (PAI) adalah suatu upaya membentuk peserta didik, dapat belajar, butuh belajar, terdorong belajar, mau belajar dan tertarik untuk terus menerus mempelajari Agama Islam, baik untuk mengetahui bagaimana cara beragama yang benar maupun mempelajari Islam sebagai penguatan

Guru merupakan jabatan atau profesi yang memerlukan keahlian khusus sebagai untuk mensukseskan kewajiban dalam profesinya. Pekerjaan ini tidak bisa dilakukan oleh orang lain yang tidak memiliki keahlian untuk melakukan kegiatan atau pekerjaan sebagai guru, guru merupakan sosok manusia yang senantiasa membimbing, memberikan contoh teladan, serta mengajarkan Ilmu yang ada kepada peserta didik. Sebagai seorang guru, hendaklah seorang mampu menjaga pembicaraan, perbuatan tingkah laku serta tindakan yang dapat membuat murid kehilangan pedoman untuk ditiru. Apalagi sebagai seorang guru Agama Islam, ia harus mengajarkan dan memberikan binaan serta memberikan contoh teladan pada peserta didik bagaimana cara berakhlak sesuai ajaran Islam.

Para guru memiliki peran yang cukup penting terhadap tingkat kedisiplinan peserta didik di Sekolah. Akan lebih baik lagi jika para guru di Sekolah menanamkan pada peserta didik setiap kali proses belajar mengajar berlangsung maupun di luar proses pembelajaran, selama peserta didik itu masih berada di lingkungan Sekolah. Dengan begitu, para peserta didik seakan diingatkan betapa pentingnya pengaruh disiplin terhadap prestasi belajar. Disiplin harus selalu diberikan melalui contoh, tidak hanya berupa penjelasan yang nantinya hanya dianggap angin lalu oleh peserta didik. Hal ini terjadi disebabkan karena adanya faktor yang ada dalam diri individu (faktor intern) dan faktor di luar individu (faktor ekstern).

Pendidikan Agama Islam bertujuan agar mampu membentuk kepribadian dan kedisiplinan yang sifatnya hakiki dalam kehidupan (Khairunnas et al., 2021; Yusuf et al., 2020). Maka adanya Pendidikan Agama Islam adalah upaya sadar dan terencana dalam menyiapkan peserta didik untuk mengenal, memahami, menghayati, hingga mengimani, bertakwa dan berakhlak mulia dalam mengamalkan ajaran Agama Islam dari sumber utamanya kitab Al-Qur'an Hadits, melalui kegiatan bimbingan, pengajaran, latihan serta penggunaan pengalaman. Disertai dengan tuntunan untuk menghormati penganut agama 
lain dalam hubunganya, dalam kerukunan antar umat beragama dalam masyarakat hingga terwujud kesatuan dan persatuan bangsa (Mursyid, 2016; M. A. Nugroho \& Ni'mah, 2018).

Berdasarkan observasi awal yang telah peneliti lakukan pada Kelas IV di SD Negeri 15 Sungai Geringging Kabupaten Padang Pariaman, terlihatlah adanya peserta didik yng kurang disiplin dalam Aspek: “Al-Qur'an, seperti kurangnya minat peserta didik menghafal surat pendek pilihan (Hafidz) juz 30. Pada Aspek Akhlak, masih ada peserta didik yang kurang memiliki sikap jujur, ikhlas, amanah dan istiqamah. Dari Aspek Fiqh, masih ada peserta didik yang tidak mau mengikuti salat berjamaah tepat waktu dan berinfaq, dari Aspek Tarikh atau Sejarah, masih ada peserta didik yang kurang meneladani Rasulullah SAW. Berdasarkan permasalahan di atas peneliti tertarik untuk meneliti tentang Implementasi Hasil Belajar PAI dalam kedisiplinan peserta didik.

\section{METHOD}

Lokasi penelitian adalah tempat di mana penelitian akan dilakukan, beserta jalan dan kotanya. Dalam penelitian ini peneliti mengambil lokasi di Sekolah Dasar Negeri 15 Sungai Geringging Kabupten Padang Pariaman. Alasan mengambil penelitian pada Kelas IV di Sekolah Dasar Negeri 15 Sungai Geringging Kabupaten Padang Pariaman, karena Sekotlah tersebuitu berdekatan dengan tempat peneliti bekerja, lamanya waktu penelitian dari 02 Maret sampai Desember 2020.

Dipilihnya Sekolah Dasar Negeri 15 Sungai Geringging Kabupaten Padang Pariaman ini karena Sekolah Dasar Negeri 15 letaknya strategis, didepan Sekolah ada lapangan bola berdampingan dengan sanggar kesenian, sebelah kanan Sekolah ada SMPN 1 Sungai Geringging, sebelah kiri rumah warga dan pasar, serta dibelakang Sekolah kurang lebih kurang 50 meter ada Mesjid pakan taranak. Jadi, peneliti ingin mengetahui bagaimana kedisiplin peserta didik Kelas IV Sekolah Dasar Negeri 15 Sungai Geringging Kabupaten Padang Pariaman yang bertempat dikeramaian, peneliti merasa sangat tepat meneliti di Kelas IV Sekolah Dasar Negeri 15 Sungai Geringging Kabupaten Padang Pariaman itu.

Jenis penelitian yang digunakan pada penelitian ini adalah deskriptif kualitatif dan kuantitatif dengan menggunakan angka-angka atau pendekatan penelitian yang mewakili paham positivisme, dengan menggunakan angka-angka atau yang diangkakan. Terdapat dua hal utama yang mempengaruhi kualitas data hasil penelitian, yaitu kualitas instrumen pendidikan dan kualitas pengumpulan data. Dalam penelitian kualitatif, yang menjadi instrumen atau alat penelitian adalah peneliti itu sendiri. Oleh karena itu, peneliti sebagai instrumen juga harus "divalidasi” seberapa jauh peneliti kualitatif siap melakukan penelitian yang selanjutnya terjun ke lapangan. Validasi terhadap peneliti sebagai instrumen meliputi validasi terhadap pemahaman metode penelitian kualitatif, penguasaan wawasan terhadap bidang yang diteliti, kesiapan peneliti untuk memasuki obyek peneliti, baik akademik maupun logistiknya. 


\section{RESULTS \& DISCUSSION}

Sekolah Dasar Negeri 15 Sungai Geringging terletak di dekat Pasar Sungai Geringging, $10 \mathrm{~m}$ dari Pasar Sungai Geringging. Sekolah Dasar Negeri ini berdekatan dengan SMP Negeri 1 Sungai $35 \mathrm{~km}$ dari arah Utara dan sampai di Pasar Sungai Limau berbelok kearah Timur. Daerah ini terdiri dari perbukitan, sehingga jalur yang yang ditempuh kedaerah ini cukup berliku dan tahun 1973 dengan nama SD Inpres, didirikan di atas tanah hibah Ungku Syura Suku Caniago. SD ini sudah mengalami dua kali perubahan nama, pada tahun 1988 SD Inpres diganti dengan nama SD 27 dan pada tahun 2001 diganti lagi dengan nama Sekolah Dasar Negeri 15 Sungai Geringging.

Penelitian yang peneliti lakukan untuk mendapatkan data tentang Implementasi disiplin pada hasil pembelajaran Pendidikan Agama Islam di Sekolah Dasar Negeri 15 Sungai Geringging Kabupaten Padang Pariaman pada Kelas IV, yang mana penulis telah melakukan wawancara, observasi dan dokumentasi, sehingga mendapatkan data yang objektif mengenai Implementasi disiplin pada hasil pembelajaran Pendidikan Agama Islam di Sekolah Dasar Negeri 15 Sungai Geringging Kabupaten Padang Pariaman.

Disiplin adalah suatu keinginan diri sendiri untuk sukses dalam mengikuti peraturan Allah SWT dan Rasulullah SAW sebagai pedoman hidup, lalu amalkan dalam kehidupan sehari-hari, ikuti juga perintah kedua orang tua, guru dan masyarakat selagi sesuai dengan aturan yang telah ditentukan, niscaya selamat dunia akhirat.

Disiplin sangat penting diterapkan dan dilaksanakan dalam kehidupan seharihari kapanpun dan dimanapun, karena disiplin adalah upaya sadar untuk melakukan dan menjalankan perturan (Dalkir, 2005; Zuković \& Stojadinović, 2021; Nelson, 2002), tata tertib, prosedur yang telah disusun sehingga tujuan dari rencana bisa terwujud sebagimana mestinya, menjaga waktu beribadah kepada Allah SWT (Amir, 2014); (Farahani et al., 2018). Seperti menjaga waktu salat lima waktu sehari semalam, salat sunat, salat berjamaah maupun salat sendirian dengan tidak melalaikannya, menjaga waktu dengan membaca Al-Qur'an, menghafal Al-Qur'an dan menjaga waktu belajar.

Di Sekolah Dasar Negeri 15 Sungai Geringging Kabupaten Padang Pariaman, pada Aspek Al-Qur'an telah berjalan seperti Program Tahfidz pada masing-masing Kelas mulai dari Kelas rendah sampai Kelas tinggi, peserta didik juga menghafal surat pendek pilihan terkait materi pembelajaran yang telah ditentukan oleh Kurikulum dan diajarkan guru Agama Islam, aspek akhlak seperti menghormati Kepala Sekolah, majlis guru dan sesama teman, memiliki sifat jujur, ikhlas, amanah dan istiqamah, aspek fiqh seperti salat dan infaq dan aspek tarikh atau sejarah dengan disiplin peserta didik akan terbiasa dan terlatih melakukan pekerjaan ataupun tugas dengan selalu menjaga waktun meneladani sifat Rasulullah SAW dan mengatur waktunya tanpa diperintahkan dan diingatkan terlebih dahulu, kalau kedisiplinan tersebut sudah ditanamkan di dalam dirinya.

Tabel 1. Pelaksanaan Disiplin dalam Pembelajaran Pendidikan Agama Islam Aspek AlQur'an

$\begin{array}{cccc}\text { No } & \text { Surat Pendek } & \text { Kelas } & \text { Keterangan } \\ \text { 1. } & \text { AL-BALAD } & \text { IV } & \\ \text { 2. } & \text { ASY-SYAM } & \text { IV }\end{array}$


3. AL-LAIL

IV

4. ADH-DHUHA

IV

5. AL-INSYIRAH

IV

6. AT-TIIN

IV

7. AL-'ALAQ

IV

Tabel 2. Program Tahfizh Al-Qur'an atau Surat Pendek

\begin{tabular}{|c|c|c|c|c|c|c|c|c|}
\hline No & Kode & Al-Balad & $\begin{array}{l}\text { Asy- } \\
\text { Syam }\end{array}$ & Al-Lail & Ad-Duha & $\begin{array}{l}\text { Asy- } \\
\text { Syarh }\end{array}$ & At-Tiin & $\begin{array}{l}\text { Al- } \\
\text { 'Alaq }\end{array}$ \\
\hline 1. & $\mathrm{AD}$ & $\sqrt{ }$ & $\sqrt{ }$ & $\sqrt{ }$ & $\sqrt{ }$ & $\sqrt{ }$ & $\sqrt{ }$ & $\mathrm{X}$ \\
\hline 2. & AR & $\sqrt{ }$ & $\mathrm{x}$ & $\sqrt{ }$ & $\sqrt{ }$ & $\sqrt{ }$ & $\sqrt{ }$ & $\mathrm{X}$ \\
\hline 3. & AN & $\sqrt{ }$ & $\mathrm{x}$ & $\mathrm{x}$ & $\mathrm{x}$ & $\sqrt{ }$ & $\sqrt{ }$ & $\mathrm{X}$ \\
\hline 4. & AW & $\sqrt{ }$ & $\mathrm{x}$ & $\sqrt{ }$ & $\sqrt{ }$ & $\sqrt{ }$ & $\sqrt{ }$ & $\sqrt{ }$ \\
\hline 5. & BS & $\sqrt{ }$ & $\sqrt{ }$ & $\mathrm{x}$ & $\sqrt{ }$ & $\sqrt{ }$ & $\sqrt{ }$ & $X$ \\
\hline 6. & $\mathrm{DE}$ & $\sqrt{ }$ & $\sqrt{ }$ & $\sqrt{ }$ & $\sqrt{ }$ & $\sqrt{ }$ & $\sqrt{ }$ & $\mathrm{X}$ \\
\hline 7. & DM & $\sqrt{ }$ & $\mathrm{x}$ & $\sqrt{ }$ & $\sqrt{ }$ & $\sqrt{ }$ & $\sqrt{ }$ & $\mathrm{x}$ \\
\hline 8. & EA & $\sqrt{ }$ & $\mathrm{x}$ & $\mathrm{x}$ & $\mathrm{x}$ & $\sqrt{ }$ & $\sqrt{ }$ & $\mathrm{X}$ \\
\hline 9. & FM & $\sqrt{ }$ & $\sqrt{ }$ & $\sqrt{ }$ & $\sqrt{ }$ & $\sqrt{ }$ & $\sqrt{ }$ & $\sqrt{ }$ \\
\hline 10. & FL & $\sqrt{ }$ & $\mathrm{x}$ & $\mathrm{x}$ & $\mathrm{x}$ & $\sqrt{ }$ & $\sqrt{ }$ & $\mathrm{x}$ \\
\hline 11. & LA & $\sqrt{ }$ & $\mathrm{x}$ & $\mathrm{x}$ & $\mathrm{X}$ & $\sqrt{ }$ & $\sqrt{ }$ & $\mathrm{X}$ \\
\hline 12. & $\mathrm{ME}$ & $\mathrm{x}$ & $\mathrm{x}$ & $\mathrm{x}$ & $\mathrm{x}$ & $\sqrt{ }$ & $\sqrt{ }$ & $\mathrm{x}$ \\
\hline 13. & ND & $\sqrt{ }$ & $\mathrm{x}$ & $\mathrm{x}$ & $\mathrm{x}$ & $\sqrt{ }$ & $\sqrt{ }$ & $\mathrm{x}$ \\
\hline 14. & NO & $\sqrt{ }$ & $\sqrt{ }$ & $\sqrt{ }$ & $\sqrt{ }$ & $\sqrt{ }$ & $\sqrt{ }$ & $\sqrt{ }$ \\
\hline 15. & NY & $\sqrt{ }$ & $\sqrt{ }$ & $\sqrt{ }$ & $\sqrt{ }$ & $\sqrt{ }$ & $\sqrt{ }$ & $\sqrt{ }$ \\
\hline 16. & $\mathrm{NZ}$ & $\mathrm{x}$ & $\mathrm{x}$ & $\mathrm{x}$ & $\sqrt{ }$ & $\sqrt{ }$ & $\sqrt{ }$ & $\mathrm{x}$ \\
\hline 17. & NR & $\sqrt{ }$ & $\sqrt{ }$ & $\mathrm{x}$ & $\sqrt{ }$ & $\sqrt{ }$ & $\sqrt{ }$ & $\mathrm{x}$ \\
\hline 18. & $\mathrm{RN}$ & $\sqrt{ }$ & $\mathrm{x}$ & $\mathrm{x}$ & $\sqrt{ }$ & $\sqrt{ }$ & $\sqrt{ }$ & $\mathrm{X}$ \\
\hline 19. & $\mathrm{RF}$ & $\sqrt{ }$ & $\mathrm{X}$ & $\sqrt{ }$ & $\sqrt{ }$ & $\sqrt{ }$ & $\sqrt{ }$ & $\mathrm{X}$ \\
\hline 20. & RY & $\sqrt{ }$ & $\sqrt{ }$ & $\sqrt{ }$ & $\mathrm{X}$ & $\sqrt{ }$ & $\sqrt{ }$ & $\mathrm{X}$ \\
\hline 21. & RV & $\mathrm{X}$ & $\mathrm{X}$ & $\mathrm{X}$ & $\sqrt{ }$ & $\sqrt{ }$ & $\sqrt{ }$ & $\mathrm{X}$ \\
\hline 22. & SF & $\sqrt{ }$ & $\mathrm{X}$ & $\sqrt{ }$ & $\sqrt{ }$ & $\sqrt{ }$ & $\sqrt{ }$ & $\mathrm{x}$ \\
\hline 23. & VO & $\mathrm{x}$ & $\mathrm{x}$ & $\sqrt{ }$ & $\sqrt{ }$ & $\sqrt{ }$ & $\sqrt{ }$ & $\mathrm{X}$ \\
\hline 24. & $\mathrm{ZH}$ & $\sqrt{ }$ & $\mathrm{x}$ & $\mathrm{X}$ & $\sqrt{ }$ & $\sqrt{ }$ & $\sqrt{ }$ & $\sqrt{ }$ \\
\hline 25. & ZQ & $\sqrt{ }$ & $\sqrt{ }$ & $\sqrt{ }$ & $\sqrt{ }$ & $\sqrt{ }$ & $\sqrt{ }$ & $\mathrm{x}$ \\
\hline & & 84 & 36 & 52 & 72 & 100 & 100 & 20 \\
\hline
\end{tabular}

Dari tabel di atas dapat disimpulkan bahwa: "Peserta didik yang hafal Surat AlBalad sebanyak 21 orang ( $84 \%$ ), peserta didik yang hafal surat Asy-Syam sebanyak 8 orang (32\%), peserta didik yang hafal surat Al-Lail sebanyak 52 orang (52\%), peserta didik yang hafal surat Ad-Duha sebanyak 72 orang (72\%), peserta didik yang hafal surat Asy-Syarh sebanyak orang (100\%), peserta didik yang hafal surat At-Tiin sebanyak 21 orang $(100 \%)$, peserta didik yang hafal surat Al-'Alaq sebanyak 21 orang $(20 \%)$ ".

Berdasarkan hasil observasi yang peneliti lakukan. Implementasi disiplin pada kelas IV saat pembelajaran Pendidikan Agama Islam di SD Negeri 15 Sungai 
Geringging. Bahwa Ketika dalam proses pembelajaran Pendidikan Agama Islam saya melihat pelaksanaan disiplin pada Aspek Al-Qur'an, guru Agama Islam membaca bersama peserta didik satu surat pendek, ketika akan memulai pembelajaran dan satu surat pendek ketika akan pulang, Program Tahfidz tersebut sudah dibagi masing-masing Kelas, pada kelas IV ada 8 Surat pendek 1 surat terkait materi pembelajaran Pendidikan Agama Islam tentang Al-Qur'an yaitu Surat al-falaq dan 7 surat pendek yang lain diantaranya: Surat al-balad, asy-syam, al-lail, ad-duha, asy-syarh, at-tin dan al-alaq, untuk semester 1 peserta didik diminta menyetorkan atau melaporkan 4 surat pendek dan boleh juga semua surat, karena 7 surat tersebut untuk 2 semester di Kelas IV, diluar kelas atau diluar jam pembelajaran guru agama Islam juga menerima laporan peserta didik yang mau menyetorkan hafalan surat pendeknya bagi peserta didik yang sudah hafal.

Pembiasaan membaca al-Qur'an sebagaimana yang ditegaskan oleh para peneliti semestinya dapat membentuk kedisiplinan pembacanya (Gumati, 2020). Keberadaan ajaran Islam yang sangat kental dengan disiplin mengharuskan setiap orang muslim memiliki kesadaran untuk mematuhi setiap peraturan, tata tertib yang telah diberlakukan (Nurhayati \& Ab, 2020). Anwar dalam kesimpulannya menegaskan bahwa keberadaan pembelajaran Alquran dapat mendukung terbentuknya karakter peserta didik (Anwar, 2021).

\section{Pelaksanaan Disiplin dalam Pembelajaran Pendidikan Agama Islam Aspek Akhlak}

Tabel 3. Akhlak Peserta Didik di SD Negeri 15 Sungai Geringging

\begin{tabular}{|c|c|c|c|c|c|}
\hline No & Kode & Jujur & Ikhlas & Amanah & Istiqamah \\
\hline 1. & AD & $\sqrt{ }$ & $\sqrt{ }$ & $\sqrt{ }$ & $\sqrt{ }$ \\
\hline 2. & AR & $\mathrm{x}$ & $\sqrt{ }$ & $\sqrt{ }$ & $\sqrt{ }$ \\
\hline 3. & AN & $\mathrm{x}$ & $\sqrt{ }$ & $\sqrt{ }$ & $\mathrm{x}$ \\
\hline 4. & $\mathrm{AW}$ & $\sqrt{ }$ & $\sqrt{ }$ & $\sqrt{ }$ & $\sqrt{ }$ \\
\hline 5. & $\mathrm{BS}$ & $\sqrt{ }$ & $\sqrt{ }$ & $\sqrt{ }$ & $\sqrt{ }$ \\
\hline 6. & DE & $\mathrm{x}$ & $\sqrt{ }$ & $\sqrt{ }$ & $\mathrm{x}$ \\
\hline 7. & DM & $\sqrt{ }$ & $\sqrt{ }$ & $\sqrt{ }$ & $\mathrm{x}$ \\
\hline 8. & EA & $\mathrm{x}$ & $\sqrt{ }$ & $\sqrt{ }$ & $\mathrm{x}$ \\
\hline 9. & FM & $\sqrt{ }$ & $\sqrt{ }$ & $\sqrt{ }$ & $\sqrt{ }$ \\
\hline 10. & FL & $\sqrt{ }$ & $\sqrt{ }$ & $\sqrt{ }$ & $\mathrm{x}$ \\
\hline 11. & LA & $\mathrm{x}$ & $\sqrt{ }$ & $\sqrt{ }$ & $\sqrt{ }$ \\
\hline 12. & ME & $\mathrm{x}$ & $\sqrt{ }$ & $\sqrt{ }$ & $\mathrm{x}$ \\
\hline 13. & ND & $\sqrt{ }$ & $\sqrt{ }$ & $\sqrt{ }$ & $\sqrt{ }$ \\
\hline 14. & NO & $\sqrt{ }$ & $\sqrt{ }$ & $\sqrt{ }$ & $\sqrt{ }$ \\
\hline 15. & NY & $\sqrt{ }$ & $\mathrm{x}$ & $\sqrt{ }$ & $\sqrt{ }$ \\
\hline 16. & NZ & $\sqrt{ }$ & $\sqrt{ }$ & $\mathrm{X}$ & $\mathrm{x}$ \\
\hline 17. & NR & $\sqrt{ }$ & $\sqrt{ }$ & $\sqrt{ }$ & $\sqrt{ }$ \\
\hline 18. & RN & $\sqrt{ }$ & $\sqrt{ }$ & $\mathrm{X}$ & $\mathrm{x}$ \\
\hline 19. & RF & $\sqrt{ }$ & $\mathrm{x}$ & $\mathrm{X}$ & $\sqrt{ }$ \\
\hline 20. & RY & $\sqrt{ }$ & $\mathrm{x}$ & $\sqrt{ }$ & $\sqrt{ }$ \\
\hline 21. & RV & $\sqrt{ }$ & $\sqrt{ }$ & $\mathrm{X}$ & $\mathrm{x}$ \\
\hline 22. & SF & $\sqrt{ }$ & $\mathrm{x}$ & $\sqrt{ }$ & $\sqrt{ }$ \\
\hline 23. & VO & $\sqrt{ }$ & $\sqrt{ }$ & $\sqrt{ }$ & $\sqrt{ }$ \\
\hline 24. & ZH & $\sqrt{ }$ & $\sqrt{ }$ & $\sqrt{ }$ & $\mathrm{x}$ \\
\hline
\end{tabular}




\begin{tabular}{|c|c|c|c|c|c|}
\hline 25. & ZQ & $\sqrt{ }$ & $\mathrm{x}$ & $\sqrt{ }$ & $\sqrt{ }$ \\
\hline & & $\mathbf{7 6}$ & $\mathbf{8 0}$ & $\mathbf{8 4}$ & $\mathbf{6 0}$ \\
\hline
\end{tabular}

Dari tabel di atas dapat disimpulkan bahwa: "Peserta didik yang memiliki sifat jujur sebanyak 19 orang (76\%), peserta didik yang memiliki sifat Ikhlas sebanyak 20 orang $(80 \%)$, peserta didik yang memiliki sikap amanah sebanyak 21 orang $(84 \%)$ peserta didik yang memiliki sikap istiqomah sebanyak 15 orang $(60 \%)$ ". Bahwa ada beberapa orang peserta didik yang kurang jujur berbicara dengan Kepala Sekolah, hal tersebut terlihat ketika Kepala Sekolah memberikan pertanyaan apakah ada peserta didik ibuk melakukan salat subuh di rumah tadi pagi, hal itu ditanyakan pada saat Kepala Sekolah memberikan pesan atau nasehat saat berbaris dilapangan setelah guru Agama Islam memberikan nasehat pada kegiatan kultum jum'at. Ada beberapa orang peserta didik yang awalnya mengatakan salat subuh, setelah beberapa saat ditanya lagi, dan menjawab tidak melaksanakan salat subuh dengan alasan karena ketiduran, semalam tidurnya telat, dan salah seorang dari peserta didik yang tidak mendengarkan ketika kepala sekolah berbicara dengan menoleh ke kiri dan ke kanan, ada juga yang berbiacara dengan temannya tanpa mendengarkan teguran dari Kepala Sekolah dan majelis guru dan mengulangi perbuatannya kembali seperti: Berbicara dengan sesama teman sekelasnya, baik pada saat belajar di dalam Kelas, saat berbaris maupun saat di luar kelas dengan menggunakan perkataan yang kurang baik.

Pada saat bergurau ada salam seorang peserta didik yang mengeluarkan perkataan yang kurang baik seperti waang, aden, matilah ang atau bergurau dengan kata-kata yang berlebihan, sehingga membuat temannya merasa tersinggung. Ada juga peserta didik yang mencubit-cubit dan menggelitik temannya ketika sedang belajar, menulis dan membaca, mengambil pena ataupun barang yang ada didekat temannya sehingga membuat temannya terganggu dan marah.

Terkadang ada peserta didik yang menyimpan barang milik temannya dengan maksud bergurau tanpa sepengetahuan temannya tersebut, sehingga membuat temannya sedih dan pusing mencari barang yang ia punya kesana kemari. Ada beberapa peserta didik yang memanggil temannya dengan nama orang tua sambil tersenyum-senyum, sehingga membuat peserta didik tersebut marah dan melaporkan perbuatan tersebut kepada guru kelas dan guru Agama Islam.

Penulis melihat bahwa ada beberapa orang peserta didik yang tidak ikhlas ketika mengerjakan tugas yang diberikan oleh guru, baik tugas yang diberikan di Sekolah untuk dikerjakan saat jam pelajaran berlangsung dan tugas yang diberikan untuk dikerjakan di Rumah, seperti tugas menulis maupun menghafal surat pendek yang diberikan oleh gurunya, hal tersebut dapat dilihat ketika guru meminta kepada peserta didik untuk mengumpulkan tugas tersebut dan menyetorkan hafalan surat pendeknya.

Ada beberapa orang peserta didik yang tidak amanah dengan tidak mengumpulkan tugasnya dan memberikan alasan bukunya tinggal di Rumah, lupa dan untuk hafalan surat pendeknya ada beberapa orang peserta didik yang baru hafal setengah surat padahal ketika guru Agama meminta untuk melaporkan surat pendek yang pertama, guru Agama Islam sudah masuk pada setoran ayat yang ke dua. Hal tersebut juga menunjukkan ada beberapa orang peserta didik yang kurang amanah dalam mengerjakan kepercayaan yang diberikan oleh guru, meskipun demikian guru Agama Islam tetap memberikan nasehat dan kesempatan kepada peserta didik agar tidak terus menerus lalai dan menyepelekan tugas dan amanah yang diberikan.

Ada beberapa orang peserta didik yang tidak memiliki sifat istiqamah hal tersebut terlihat ketika guru memberikan tugas hari ini, untuk dikumpulkan hari ini juga, 
ada yang mengumpulkan tepat waktu dan ada juga peserta didik yang tidak mengumpulkan tugasnya. Bagi peserta didik yang mengumpulkan hari ini, untuk tugas selanjutnya guru memeriksa ada dianatara mereka ada yang tidak mengumpulkan.

Table 4. Disiplin pada Pembelajaran Fiqh

\begin{tabular}{|c|c|c|c|}
\hline No & Nama & Shalat & Infaq \\
\hline 1. & $\mathrm{AD}$ & $\sqrt{ }$ & $\mathrm{X}$ \\
\hline 2. & AR & $\sqrt{ }$ & $\sqrt{ }$ \\
\hline 3. & AN & $X$ & $\sqrt{ }$ \\
\hline 4. & AW & $\sqrt{ }$ & $\sqrt{ }$ \\
\hline 5. & BS & $\sqrt{ }$ & $\sqrt{ }$ \\
\hline 6. & DE & $\sqrt{ }$ & $\mathrm{x}$ \\
\hline 7. & DM & $\sqrt{ }$ & $\sqrt{ }$ \\
\hline 8. & EA & $\sqrt{ }$ & $\sqrt{ }$ \\
\hline 9. & FM & $\sqrt{ }$ & $\sqrt{ }$ \\
\hline 10. & FL & $\sqrt{ }$ & $\sqrt{ }$ \\
\hline 11. & LA & $\sqrt{ }$ & $\mathrm{X}$ \\
\hline 12. & ME & $\sqrt{ }$ & $\mathrm{x}$ \\
\hline 13. & ND & $\sqrt{ }$ & $\sqrt{ }$ \\
\hline 14. & NO & $\sqrt{ }$ & $\sqrt{ }$ \\
\hline 15. & NY & $\sqrt{ }$ & $\sqrt{ }$ \\
\hline 16. & NZ & X & $\sqrt{ }$ \\
\hline 17. & NR & $\sqrt{ }$ & $\sqrt{ }$ \\
\hline 18. & RN & $\sqrt{ }$ & $\mathrm{x}$ \\
\hline 19. & RF & $\sqrt{ }$ & $\sqrt{ }$ \\
\hline 20. & RY & $\sqrt{ }$ & $\mathrm{X}$ \\
\hline 21. & RV & X & $\sqrt{ }$ \\
\hline 22. & SF & $\sqrt{ }$ & $\sqrt{ }$ \\
\hline 23. & VO & $\sqrt{ }$ & $\sqrt{ }$ \\
\hline 24. & $\mathrm{ZH}$ & $\sqrt{ }$ & $\sqrt{ }$ \\
\hline \multirow[t]{2}{*}{25.} & ZQ & $\sqrt{ }$ & $\sqrt{ }$ \\
\hline & & 80 & 76 \\
\hline
\end{tabular}

Dari tabel di atas dapat disimpulkan bahwa: Peserta didik yang melaksanakan salat sebanyak 22 orang $(80 \%)$ dan peserta didik yang berinfaq sebanyak 19 orang (76\%).

Berdasarkan observasi yang penulis lakukan bahwa pada waktu salat zuhur masuk, guru agama Islam memerintahkan kepada peserta didik untuk melaksanakan salat zuhur berjamaah, sebelum melaksanakan salat berjamaah maka peserta diingatkan untuk mengambil air wudu' terlebih dahulu.

Peserta didik yang disiplin dalam menjaga waktu dengan cepat pergi kemushalla membentangkan sajadah dan tikar setelah itu bergegas pergi ke kamar mandi untuk mengambil air wudu', untuk yang menjadi imamnya adalah salah seorang dari peserta didik kelas IV, ada beberapa orang peserta didik yang cuek dan tidak mau melaksanakan salat berjamaah dengan cara hanya berdiam diri dan tidak menyegerakan untuk mengambil air wudu' meskipun temannya sudah mengumandangkan azan dengan lantang, hal tersebut tidak dibiarkan oleh guru agama, peserta didik tersebut diberikan nasehat supaya bergegas untuk mengambil air wudu' karena salat zuhur berjamaah akan segera dimulai sebelum dimulai setelah mengumandangkan azan, peserta didik membaca bersama-sama do'a sesudah azan dengan dipimpin oleh salah 
seorang peserta didik yang telah mengumandangkan azan, sambil menunggu temannya yang lain peserta didik membaca salawat Nabi, setelah itu salat akan segera dilaksanakan.

Table 5. Kedisiplinan Peserta Didik pada Pembelajaran Tarikh

\begin{tabular}{|c|c|c|}
\hline No & Nama & Nabi Muhammad SAW \\
\hline 1. & $\mathrm{AD}$ & $\sqrt{ }$ \\
\hline 2. & AR & $\sqrt{ }$ \\
\hline 3. & $\mathrm{AN}$ & $\mathrm{X}$ \\
\hline 4. & AW & $\sqrt{ }$ \\
\hline 5. & BS & $\sqrt{ }$ \\
\hline 6. & $\mathrm{DE}$ & $\sqrt{ }$ \\
\hline 7. & $\mathrm{DM}$ & $\sqrt{ }$ \\
\hline 8. & EA & $\mathrm{X}$ \\
\hline 9. & FM & $\sqrt{ }$ \\
\hline 10. & FL & $\sqrt{ }$ \\
\hline 11. & LA & $\sqrt{ }$ \\
\hline 12. & ME & $\mathrm{X}$ \\
\hline 13. & ND & $\sqrt{ }$ \\
\hline 14. & NO & $\sqrt{ }$ \\
\hline 15. & NY & $\sqrt{ }$ \\
\hline 16. & NZ & $\sqrt{ }$ \\
\hline 17. & NR & $\sqrt{ }$ \\
\hline 18. & $\mathrm{RN}$ & $\mathrm{X}$ \\
\hline 19. & $\mathrm{RF}$ & $\sqrt{ }$ \\
\hline 20. & RY & $\sqrt{ }$ \\
\hline 21. & RV & $\mathrm{X}$ \\
\hline 22 . & $\mathrm{SF}$ & $\sqrt{ }$ \\
\hline 23. & $\mathrm{VO}$ & $\sqrt{ }$ \\
\hline 24. & $\mathrm{ZH}$ & $\sqrt{ }$ \\
\hline \multirow[t]{2}{*}{25} & $\mathrm{ZQ}$ & $\sqrt{ }$ \\
\hline & & 80 \\
\hline
\end{tabular}

Dari tabel di atas dapat disimpulkan bahwa: Peserta didik yang miliki sifat meneladani atau menjadikan Rasulullah SAW sebagai contoh teladan sebanyak 20 orang (80\%). Guru Agama Islam memberikan materi tentang keteladanan khususnya mengenai pelajaran kelas IV, dengan menayangkan video pembelajaran dengan menggunakan leptop dan infokus di depan Kelas, peserta didik antusias menyaksikan video tersebut, setelah selesai menyaksikannya peserta didik diperintahkan masingmasing mereka mengambil kesimpulan pembelajaran dari video tersebut dan menuliskannya di dalam buku catatan setelah itu dibacakan di dalam kelas. Tujuannya agar peserta didik mencontoh dan menjadikannya teladan dalam kehidupannya seharihari.

Seperti keteladanan Rasulullah SAW tentang saling menghormati antara sesama, guru mencontohkan kepada peserta didik seperti apa menghormati Kepala Sekoalah, majelis guru dan teman sebaya. Baik dalam cara berbicara yang baik dan sopan, memberikan kesempatan kepada teman dalam memberikan pendapat pada saat pembelajaran berlangsung maupun pada saat bermain di luar kelas. Pada saat pembelajaran Pendidikan Agama Islam ada beberapa orang dari peserta didik yang tidak 
menghormati guru saat berbicara, ketika diberi nasehat peserta didik tersebut melihat kekiri dan kekanan tanpa menghiraukan nasehat yang diberikan kepadanya.

Tetapi ada juga peserta didik yang terdiam dan memperhatikan nasehat dari gurunya dengan memandang penuh kefokusan dan tersenyum hal tersebut terlihat ketika guru memberikan asehat kepada semua peserta didik tanpa membedakan antara peserta didik yang patuh dengan yang tidak patuh. Dalam hal memberikan bantuan atau menolong kepala sekolah, majelis guru maupun teman sebaya penulis melihat ada beberapa orang peserta didik memberikan bantuan kepada kepala sekolah dengan menanyakan apa yang bisa dibantu buk, hal tersebut terlihat pada saat kepala sekolah membersihkan halaman sekolah dengan membantu menyapu dan memilih sampah. Ada juga peserta didik yang membantu guru membawakan buku paket agama untuk dibawa kekantor tanpa diminta, selain itu ada juga peserta didik yang diminta tolongi dulu oleh guru tersebut. Membantu teman sebaya dengan cara memberikan contoh kepada temannya, ketika teman tersebut tidak mengerti dengan pelajaran dan membantu saat menghafal pelajaran atau tugas maupun ayat pendek dengan mendengarkannya, tetapi juga ada peserta didik yang pelit ketika temannya bertanya, ia malah diam dan tidak menjawab pertanyaan dari temannya tersebut.

\section{CONCLUSIONS}

Sesuai dengan hasil penelitian yang dijelaskan diketahui bahwa disiplin peserta didik pada pembelajaran PAI terimplementasi dalam lingkungan sekolah. Kesimpulan ini didasarkan pada data yang terkait dengan kedisiplinan peserta didik pada aspek pembelajaran akhlak, dimana peserta didik memiliki sikap amanah, jujur, rajin serta akhlak terpuji lainnya. Selain itu, dengan pembelajaran pada aspek fiqih, peserta didik memiliki disiplin dalam beribadah baik di lingkungan sekolah maupun di lingkungan tempat tinggal. Melalui pembelajaran sejarah kebudayaan Islam terlihat kedisiplinan peserta didik dengan mencontoh dan meneladani kepribadian Rasulullah.

Dari temuan yang ada peneliti mensarankan kepada berbagai pihak, Pihak sekolah harus mengerjakan kerja sama yang lebih, dengan para tua peserta didik, sehingga kedisiplinan peserta didik pada aspek Al-Qur'an, akhlak, fiqh dan sejarah bisa dijaga dan terkontrol dengan baik di Rumah. Bagi Kepala Sekolah, hendaknya memberikan penugasan kepada majelis guru untuk aktif dalam melaksanakan disiplin pada aspek al-Qur'an, memberikan nasehat dan motivasi kepada majelis guru untuk membaca bersama-sama hafalan surat pendek atau program tahfidz ketika akan memulai pembelajaran dan setelah selesai pembelajaran setiap harinya.

Bagi Majelis Guru, hendaknya guru memberikan nasehat dan motivasi kepada peserta didik untuk terus menghafal, menambah hafalan dan tidak malu untuk melaporkan hafalan surat pendeknya kepada guru Agama Islam walapun di luar jam pembelajaran, baik setelah melaksanakan salat zuhur berjamaah di mushala maupun pergi keruangan guru untuk melaporkan atau membacakannya dan menemani guru Pendidikan Agama Islam untuk mengawasi peserta didik dalam mengerjakan salat 
berjamaah mulai dari peserta didik mengambil air wudu sampai selesai salat berjamaah dan membaca hafalan surat pendek yang telah diprogramkan.

\section{BIBILIOGRAPHY}

Amir, D. (2014). "On Time and Discipline in Islam" (Analysis Towards Purpose of Islamic Education). Al-Ta Lim Journal, 21(3), 220-226. https://doi.org/10.15548/jt.v21i3.107

Anwar, R. N. (2021). Pendidikan Alquran (TPQ) Sebagai Upaya Membentuk Karakter Pada Anak. Jurnal Pendidikan Dan Konseling (JPDK), 3(1), 44-50. https://doi.org/10.31004/jpdk.v2i2.1342

Barrett, P., Davies, F., Zhang, Y., \& Barrett, L. (2015). The impact of classroom design on pupils' learning: Final results ofaholistic, multi-level analysis. Building and Environment, 89, 118-133. https://doi.org/10.1016/j.buildenv.2015.02.013

Dalkir, K. (2005). Knowledge Management in Theory and Practice. In Journal of the American Society for Information Science and Technology (Vol. 62, Issue 10). Elsevier. https://doi.org/10.1002/asi.21613

Dzivhani, M. D. (2000). The Role of Discipline in School and Classroom Management: A Case Study. In University of South Africa. University of South Africa.

Farahani, N. G.-K., Jodaki, M. Z., \& Nabavi, S. M. (2018). Self-Discipline Factors based on Islam Training Thought. International Journal of Multicultural and Multireligious Understanding, $\quad 5(6), \quad 250-263$. https://doi.org/http://dx.doi.org/10.18415/ijmmu.v5i6.1206

Gui, A. K. W., Yasin, M., Abdullah, N. S. M., \& Saharuddin, N. (2020). Roles of teacher and challenges in developing students' morality. Universal Journal of Educational Research, 8(3C), 52-59. https://doi.org/10.13189/ujer.2020.081606

Gumati, R. W. (2020). Pengaruh Pembiasaan Tilawah Al-Qur'an Terhadap Pembentukan Karakter Siswa. Zulfikri Sari Pediatri, 02(02), 38-57.

Khairunnas, Ritonga, M., \& Lahmi, A. (2021). Pendididkan Agama Islam sebagai Basic Kedisiplinan: Studi Fenomenologi di SMP Negeri 3 Lembah Melintang Pasaman Barat. Al-Muaddib:Jurnal Ilmu-Ilmu Sosial Dan Keislaman, 6(1), 55-65. https://doi.org/10.31604/muaddib.v5i1.55-65

Mursyid, S. (2016). Konsep Toleransi (Al-Samahah) Antar Umat Beragama Perspektif Islam. Aqlam: Journal of Islam and Plurality, 2(1), 35-51.

Nelson, M. F. (2002). A qualitative study of effective school discipline practices [East Tennessee State University]. https://doi.org/718. https://dc.etsu.edu/etd/718 
Nugroho, A. (2020). Penanaman Karakter Disiplin pada Siswa Sekolah Dasar. FUNDADIKDAS: Fundamental Pendidikan Dasar, 3(2), 90-100. http://journal2.uad.ac.id/index.php/fundadikdas/article/view/2304/pdf

Nugroho, M. A., \& Ni'mah, K. (2018). Konsep Pendidikan Islam Berwawasan Kerukunan pada Masyarakat Multikultural. Millah:Jurnal Studi Agama, 17(2), 337-378. https://doi.org/10.20885/millah.vol17.iss2.art8

Nurhayati, \& Ab, H. (2020). Strategi Guru dalam Membangun Kedisiplinan Belajar Siswa. Jurnal Pendais, 2(1), 72-89. https://www.google.com/search?q=Nurhayati\%2C+\%26+Ab\%2C+H.+(2020). $+\mathrm{Str}$ ategi + Guru + dalam + Membangun + Kedisiplinan+Belajar+Siswa. + Jurnal+Pendais $\%$ $2 \mathrm{C}+2(1) \% 2 \mathrm{C}+7289 . \&$ oq $=$ Nurhayati $\% 2 \mathrm{C}+\% 26+\mathrm{Ab} \% 2 \mathrm{C}+\mathrm{H} .+(2020) .+$ Strategi $+\mathrm{Gu}$ $\mathrm{ru}+$ dalam+Membangun + Kedisiplinan+Belajar+Siswa. + Jur

Schunk, D. H. (2012). Learning Theories an Educational Perspective. In Space Science Reviews (Issue 6). University of North Carolina at Greensboro. https://doi.org/10.1007/BF00751323

Yusuf, M., Ritonga, M., \& Mursal. (2020). Implementasi Karakter Disiplin dalam Kurikulum 2013 Pada Bidang Studi PAI di SMA Islam Terpadu Darul Hikmah. Jurnal Tarbiyatuna, 11(1), 49-60. https://doi.org/https://doi.org/10.31603/tarbiyatuna.v11i1.3437

Zuković, S., \& Stojadinović, D. (2021). Applying positive discipline in school and adolescents' self-esteem. International Journal of Cognitive Research in Science, Engineering and Education, 9(1), 1-11. https://doi.org/10.23947/2334-8496-20219-1-1-11 